\title{
DIDAKTIČKI PRISTUPI UPOTREBE IKT U NASTAVNOM PROCESU
}

\author{
Zoran Stanković1, \\ Univerzitet u Nišu, Filozofski fakultet u Nišu, Departman za pedagogiju \\ Dragana Stanojević \\ Univerzitet u Nišu, Pedagoški fakultet u Vranju
}

\begin{abstract}
Apstrakt: Savremena obrazovna tehnologija zauzima sve značajnije mesto u nastavnom procesu. Između ostalog, njena elementarna uloga ogleda se u selekciji metoda i sinhronizovanom kombinovanju različitih uređaja za nastavu, uz korišćenje informaciono-komunikacione tehnologije (IKT) i multimedijalnih paketa za učenje, koji su primereni uzrastu i potrebama učenika. Adekvatnom primenom učenicima se pruža mogućnost da racionalnije razmišljaju, analiziraju, zaključuju i postižu značajno bolje rezultate koji vode ka efikasnijem aktivnom i trajnom sticanju znanja.

Osnovni cilj ovog rada je da široj pedagoškoj stručnoj i naučnoj javnosti skrene pažnju, i ukaže na širi spektar uloge i mogućnosti koje pruža upotreba IKT u nastavnom procesu. U tom smislu, u radu se pored teorijskih razmatranja posmatranih kroz didaktičku prizmu, prenose i analiziraju neka pozitivna inostrana iskustva iz nastavne prakse..
\end{abstract}

Ključne reči: obrazovna tehnologija, IKT, multi/medij, obrazovni softver, nastavni proces.

\section{Uvod}

U ovom radu osvrnućemo se na neke didaktičko-metodičke poglede i inostrana iskustva, vezana za primenu kompjutera (kao centralne komponente IKT sistema), obrazovnog računarskog softvera (ORS-a), kao i na elemente individualizovanog rada (samostalni rad učenika, samo/učenje, rešavanje problema, tehnika individualizovanog učenja itd.) u okvirima primene IKT u nastavnom procesu.

Savremena škola je ona koja održava tempo sa tehnološkim promenama u cilju efektivnog korišćenja ovog znanja u procesu nastave i učenja i redovno implementira nove tehnologije u kurikulum. Dobra škola ne drži predavanja o tehnologiji, već

\footnotetext{
${ }^{1}$ zoran.stankovic@filozofski.rs
} 
je koristi za predavanja. Kako ističe Kapur (2011: 88), škole moraju da se odreknu razmišljanja o „računarima koji drže nastavu” učenicima, s obzirom da je to mali deo IKT sistema. Prava škola razume da računari i tehnologija jesu veoma moćna i produktivna sredstva za učenje. Tako, đaci uče kako da budu u toku sa tehnološkim razvojnim tempom da bi uvećali produktivno učenje tokom celog života. Računari se ne koriste samo za izučavanje različitih školskih predmeta kroz upotrebu multimedijalne tehnologije, već i da obezbede sredstva za međuintegraciju predmeta, i za grupno i plenarno učenje. Tehnologija je sredstvo koje omogućava učenicima da uče uz pomoć različitih stilova učenja i pojačava različite vidove saznanja. Upotreba tehnologije u tehnikama učenja je od značaja zbog održavanja koraka sa promenama.

\section{Teorijska razmatranja $i$ inostrana iskustva}

Poslednjih godina se pojačao apel školama da se priključe novim medijima. Oni su neophodni da bi učenicima preneli potrebna znanja i kvalifikacije, koje su im potrebne u poslovnom svetu i u slobodno vreme u kojem sve više vladaju kompjuteri i kompjuterske mreže. Svojim osobenostima sposobni su da značajno promene učenje i podučavanje u školi jer pružaju mnogo mogućnosti. Tako glase pedagoški argumenti za upotrebu novih medija u nastavi (Dichanz, 1999). Konačno bi bilo moguće da se upotrebom IKT podstakne pojedinac individualnim/individualizovanim pristupom. Zahvaljujući multimedijalnim programima apstraktni pojmovi mogu da se prikažu očigledno i interesantno kroz razne vidove njihove primene. Učenici bi mogli da istražuju nastavne sadržaje aktivno/interaktivno, mogli bi da rade samostalno i povezano u kontekstu, učili bi kooperativno (putem saradnje) i konstruktivno.

Bila bi doduše zabluda misliti da su kompjuter i Internet sami po sebi dovoljni da bi se podstaklo kompleksno mišljenje, rešavanje problema, kreativnost i sposobnost procenjivanja. To dokazuje i studija Velinskog (Wenglinsky, 1998) u kojoj je dokazana veza između rezultata u nastavi matematike i načina upotrebe kompjutera. Rezultati bi se popravili samo kada su korišćeni kompjuteri da bi se podučavale strategije mišljenja višeg stepena. Međutim, pojedini nastavnici (oni retki koji ga uopšte upotrebljavaju) koriste kompjutere samo za jednostavna vežbanja (,drill” vežbanja) koja uopšte ne doprinose poboljšanju rezultata učenja i znanja iz određenog predmeta. Iako kauzalni odnos u ovoj studiji nije jasno dokazan, pronađeni rezultati predstavljaju dobar savet nastavnicima koji treba da odigraju ključnu ulogu u efektivnoj primeni novih multi/medija u nastavi.

Savremeni zahtevi idu u pravcu integracije IKT u nastavni proces kako bi se stručnim primerima moglo pokazati gde se i kako mogu koristiti kompjuteri. Sledeća didaktička teorijska razmišljanja mogu da se upotrebe za potkrepljivanje ovih zahteva. U instrukcijskoj psihologiji poslednjih decenija sve se više ukazuje na važnost konteksta učenja. Pod pojmom Situiertheit von Lernen und Kognition (situated learning, situated cognition - situaciono učenje i mišljenje) razvile su se, pogotovo na američkom području, različite teorije i modeli koji naglašavaju da je stečeno zna- 
nje relevantno kada vodi rešenju konkretnih problema, samo ako je u toku učenja bilo povezano sa kontekstom svog korišćenja. Ukoliko učenik nije u mogućnosti da poveže naučeno sa relevantnim konkretnim situacijama, njegova znanja ostaju neupotrebljiva jer se ne mogu prevesti u kongnitivne ili fizičke radnje.

U teoriji kognitivnog učenja posebna se pažnja poklanja transferu učenja. Pošto se kreće od toga da je operativno znanje prvo povezano sa situacijom korišćenja u kojoj je stečeno, postavlja se pitanje kako se to znanje može preneti na novonastalu situaciju. Najveći broj modela ovde predlažu didaktičke strategije kod kojih se pomoću raznovrsnih oblika vežbanja može podstaći transfer naučenog u različite kontekste primene.

Za sticanje kompleksnih kognitivnih veština (rešavanje problema, kritičko mišljenje), programi za uvežbavanje i inteligentni tutorski sistemi su se često dokazali kao manje pogodni. Kompleksni problemi su u tome bolji što nemaju jasno rešenje, a imaju različite strategije koje vode ka cilju, čak iako sva rešenja nisu podjednako dobra. Kod rešavanja kompleksnih problema važno je da učenici prvo uče da prepoznaju i struktuiraju problem, a zatim da stvore alternative za rešavanje koje će se upoređivati. „Drill” programi i inteligentni tutorski programi su u svojoj strukturi suviše kruti da bi mogli da se upotrebe za podsticanje ovih kompleksnih kognitivnih procesa.

Mnogo veći efekat učenja se očekuje od hipermedijalnih informacionih programa, gde učenici moraju samostalno da pronađu i integrišu relevantne informacije za zadat (ili od strane učenika formulisan) problem, kao i od simuacija, u kojima učenici putem eksperimenata i interakcije prepoznaju kompleksne veze. Zato se za podsticanje ovakvih veština predlaže korišćenje otvorenijih programskih formi kod kojih učenici imaju veliki udeo u slobodi odlučivanja i kontroli učenja. Nažalost, treba napomenuti da su istraživanja vezana za učenje kompleksnih misaonih strategija i veština još uvek siromašna i da empirijski rezultati koji već postoje ove preporuke samo delimično podržavaju.

Za hipermedijalne programe učenja do sada se nisu mogle dokazati jasne prednosti pri sticanju kongnitivnih znanja, kao i pri sticanju stručnih znanja. Često učenici postižu slabije rezultate kod učenja sa hipermedijima, nego kod učenja sa linearnim programima. Uspeh učenja kod samostalnog istraživanja i integrisanja ponuđenih informacija, izgleda, isključivo zavisi od već postojećih kognitivnih veština učenika. Pogotovo ,ispotprosečni” učenici retko profitiraju od korišćenja hipermedijalnih programa (Pregled o rezultatima istraživanja vezanih za učenje sa hipermedijima, Dillon \& Gabbard, 1998).

Nevezano za vrste programa za učenje, u istraživačkim radovima bi se uvek iznova dolazilo do saznanja da suviše velika sloboda učenja kod samostalnog učenja pomoću kompjutera mnogim učenicima predstavlja problem (Williams et al., 1995). Važan promenljiv uticaj pri tome imaju osobine učenika, kao što su predznanja i znanja strateškog učenja.

Zašto je ovo značajno za korišćenje kompjuterskih programa koji postavljaju veće zahteve za samostalnost i veštine učenika? U načelu se podržava korišćenje 
ovih programa jer su veoma uspešni u sticanju kognitivnih veština višeg reda. Kao deo nastave, koja je orijentisana ka postupcima i projektima, programi se mogu upotrebiti da bi se učenici upoznali sa samostalnim učenjem prema kome će da razvijaju i samoodgovornost. U skladu sa odgovarajućim veštinama učenika, nastavnici bi trebalo da strukturno usmere i podrže učenje pomoću ovih programa kako bi osigurali stečena stručna znanja, kao i kompetentnost koja je nezavisna od predmeta.

Obrazovni softveri na eksplicitan način reprezentuju razne strategije i tehnike podučavanja koje definiše autor i omogućavaju njihovu kontrolisanu primenu u cilju efikasnijeg usvajanja sadržaja koje učenik treba da nauči kroz korišćenje sistema. Takvim pristupom se omogućava savlađivanje gradiva prema pojedinačnim osobinama učenika, tj. svaki učenik može na sebi prilagođen način da savlada i usvoji predviđeno znanje (tzv. personalizacija učenja).

Inteligentni softverski sistemi, u najširem smislu reči, mogu se grubo definisati i kao računarski programi koji koriste znanje da bi rešili određeni problem, da bi pomogli korisniku u donošenju adekvatnih odluka, omogućili ljudima da uče ili da sami prihvataju nova znanja. Prema tome, osnovni pojmovi koji se ovde javljaju su znanje, rešavanje problema i učenje. Da bi se uspešno realizovao ma koji inteligentni sistem, moraju se razrešiti i sledeći problemi: kako da se predstavi znanje u računaru; kako da se tako reprezentovano znanje materijalizuje, i kako da se ono poveća i poboljša?

Da bi se podržalo sticanje ovih kvalifikacija, nastavnicima stoje na raspolaganju različite strategije. Tako na primer može da se modelira rešavanje kompleksnih problema, tj. nastavnici treba eksplicitno da demonstriraju kako se problem približava. Jedan stariji, ali uspešan primer za ovu metodu učenja u predmetu matematike potiče od Šoenfelda, u kome on traži od učenika da mu nose „nerešive” zadatke iz matematike, da bi on onda ove zadatke radio zajedno sa njima, na taj način što bi im pokazao korak po korak kako da strukturišu zadatak, kao i koje strategije mogu da se upotrebe za rešavanje tog zadatka.

Kod artikulacije znanja i strategija za rešavanje često se pokazalo uspešnim da se objasni tzv. „tiho” znanje (tacit knowledge) i da se time pomogne učenicima da postanu svesni tog znanja, tj. naučiti ih da raspolažu njime (Collins, 1995). Pri tome nastavnici ne bi trebalo da opišu prilaz problemu i način njegovog rešavanja samo verbalno, nego i da pokrenu učenike da objasne kako misle da reše određeni problem, i zašto su se odlučili za određen prilaz problemu. Artikulacija je veoma važna da bi se učenicima pružila mogućnost da razmene mišljenje o različitim pokušajima rešavanja kompleksnih problema, kao i da uče jedni od drugih.

Hipermedijalni programi za učenje, simulacije, mogu da se koriste kako za individualno učenje, tako i za kooperativno učenje. Kako sadržaji i zahtevi ovog sistema mogu ponekad da budu veoma kompleksni, savetujemo da se ovi programi pre koriste za kooperativno učenje u grupama, gde učenici mogu uzajamno da se pomažu i da od nastavnika dobiju odgovarajuću pohvalu (feedback). Da li je učenje u malim grupama bolje od individualnog učenja sa programima za učenje, zavisi isključivo od interakcije u grupi. Tako se grupni rad veoma pozitivno ispoljava kada 
učenici postavljaju pitanja vezana za zadatke, međusobno diskutuju o strategijama koje su im potrebne da dođu do rešenja, i na kraju zajedno dođu do rešenja. Pošto učenici ovakav odnos u grupi ne moraju da poznaju, potrebno je da nastavnik postavi i oblikuje rad u grupi.

Pored sadržajno specifičnih multimedijalnih programa, koristi se korisnički softver nevezanih sadržaja (npr. tabelarni pregledi i programi baze podataka, programi obrade teksta, Mapping programi i programi za crtanje). Prilikom učenja sa ovim programima, kompjuter ne uzima ulogu samo prenosioca informacija, već služi kao alat kojim se učenici osposobljavaju da sebi približe problem, da probleme pregledno predstave i da ih na kreativan način reše. Ovakvo gledište, vezano za aktivno korišćenje kompjutera kao „sredstva za mišljenje”, već je zastupao Papert (1980), koji je kritikovao pasivnost učenika prilikom učenja sa kompjuterizovanim programima za vežbanje, koji su razvili LOGO - kompjuterski jezik za decu. Dok učenici uče da programiraju koristeći LOGO da bi npr. nacrtali slike, stiču veštinu da na kreativan način rešavaju kompleksne probleme. Da bi rešili zadatak koji je programiran u LOGO-u, učenici moraju prvo da ga analiziraju i rastave na manje delove, da identifikuju važne informacije vezane za rešenja, dodele varijable, da uporede moguća rešenja, programske strukture, da razumeju, primene i na kraju pronađu i otklone grešku. Još uvek je, doduše, bilo nejasno koliko će se veštine koje se usvajaju putem programiranja preneti na ostale problemske kontekste.

Nastavnici bi trebalo da znaju da podrže i strukturiraju proces rešavanja problema. Kod strategije koja služi podršci, učenici prema svojoj potrebi dobijaju pomoć za rešavanje problema. Ovim se žele izbeći potencijalne frustracije i prerano odustajanje. Pri tome je važno da im nastavnici pruže puno slobode, povere odgovornost, a pomažu samo tamo gde im nedostaje veština. Pomoć bi u idealnim uslovima trebalo postepeno da se redukuje sve dok učenici ne budu u stanju da problem samostalno reše. Učenje bi na kraju trebalo da bude propraćeno refleksivnom fazom u kojoj učenici proces rešavanja još jednom rekapituliraju i razmišljaju o tome kako bi otkrivene strategije mogli da primene i na druge kontekste, tako da se naučena sposobnost rešavanja problema apstrahuje i fleksibilizuje.

Različiti programi sugerišu, na osnovu individualnosti, različite načine upotrebe. Programi za vežbanje i inteligentni tutorski sistemi najčešće su određeni za individualnu primenu, $\mathrm{tj}$. veoma su pogodni za individualno učenje. Njihova upotreba je veoma smisaona u fazama samostalnog učenja, za individualna vežbanja, npr. za izradu domaćih zadataka i kod unutrašnje diferencijacije.

U pedagoško-psihološkoj literaturi može se naći dosta primera koji ukazuju na značaj, mogućnost, spojivost i nužnost integracije različitih oblika i tehnika individualizovane nastave i učenja, uz kompjutersku i IKT podršku. Jedan od takvih pogleda (Persival \& Elington, 1988), sa glavnim prednostima i slabostima, sumirali smo i predstavili u okviru sledeće tabele (tabela 1): 


\section{Tabela 1. Karakteristike nekih tehnika individualizovanog učenja (Persival \& Elington, prema Danilović, 1996: 25-26)}

\begin{tabular}{|c|c|c|}
\hline TEHNIKA & Prednosti & Slabosti \\
\hline $\begin{array}{l}\text { Dirigovano učenje } \\
\text { materijala u } \\
\text { udžbenicima }\end{array}$ & $\begin{array}{l}\text {-Može da bude vrlo } \\
\text { delotvoran način držanja } \\
\text { nastave o bazičnim } \\
\text { činjenicama, principima, } \\
\text { aplikacijama itd., pod } \\
\text { uslovom da su nam dostupni } \\
\text { odgovarajući tekstovi i da je } \\
\text { rad pažljivo strukturisan; } \\
\text {-Omogućuje učeniku da } \\
\text { radi svojom prirodnom } \\
\text { brzinom; } \\
\text {-Ne zahteva bilo kakva } \\
\text { specijalizovana sredstva. }\end{array}$ & $\begin{array}{l}\text { - Zahteva pažljivo } \\
\text { planiranje i strukturisanje } \\
\text { od strane nastavnika; } \\
\text {-Zavisno od pogodnih } \\
\text { tekstova koji su dostupni u } \\
\text { dovoljnom broju da bi } \\
\text { zadovoljili ceo razred koji } \\
\text { sprovodi učenje; } \\
\text {-Nije pogodno za } \\
\text { ostvarivanje većine } \\
\text { kognitivnih i nekognitivnih } \\
\text { ciljeva višeg reda. }\end{array}$ \\
\hline $\begin{array}{l}\text { Proučavanje } \\
\text { specijalno } \\
\text { pripremljenih } \\
\text { beležaka ili } \\
\text { programiranih } \\
\text { tekstova }\end{array}$ & $\begin{array}{l}\text {-Iste osnovne prednosti kao } \\
\text { kod dirigovanog učenja iz } \\
\text { knjiga, a čak može da bude } \\
\text { delotvornije ukoliko su } \\
\text { materijali dobro } \\
\text { pripremljeni; } \\
\text {-Može da omogući } \\
\text { učenicima da stupaju u } \\
\text { interakciju sa materijalom. }\end{array}$ & $\begin{array}{l}\text {-Priprema odgovarajućih } \\
\text { materijala može da traži } \\
\text { trošenje velike količine } \\
\text { vremena; } \\
\text {-Takođe, nije pogodno za } \\
\text { ostvarivanje mnogih } \\
\text { kognitivnih i nekognitivnih } \\
\text { ciljeva višeg reda. }\end{array}$ \\
\hline $\begin{array}{l}\text { Samostalne } \\
\text { instrukcije } \\
\text { korišcenjem audio- } \\
\text { vizuelnih medija } \\
\text { (audio trake, video } \\
\text { trake, programi sa } \\
\text { trakama/slajdovima } \\
\text { itd.) }\end{array}$ & $\begin{array}{l}\text {-Omogućuje ostvarivanje } \\
\text { širokog opsega obrazovnih } \\
\text { ciljeva; } \\
\text {-Omogućuje učeniku da } \\
\text { radi sopstvenom brzinom; } \\
\text { - Kao dodatak, korišćnje } \\
\text { medijskih prezentacija } \\
\text { omogućuje uvoženje zvuka, } \\
\text { pokreta itd., čime se } \\
\text { uvećava stimulativnost; } \\
\text {-Može da poštedi } \\
\text { nastavnike od sprovođenja } \\
\text { repetitivnog i dugotrajnog } \\
\text { rada. }\end{array}$ & $\begin{array}{l}\text {-Idealan gotov materijal } \\
\text { nam je retko dostupan, a } \\
\text { pripremanje posebno } \\
\text { dizajniranih materijala } \\
\text { može da bude i dugotrajno i } \\
\text { skupo, a takođe zahteva i } \\
\text { specijalizovane veštine; } \\
\text {-Takođe, nije pogodno za } \\
\text { ostvarivanje mnogih } \\
\text { kognitivnih i nekognitivnih } \\
\text { ciljeva višeg reda; } \\
\text {-Ne može da bude } \\
\text { korišćeno ukoliko nam nije } \\
\text { dostupan odgovarajući } \\
\text { hardver; njegova nabavka } \\
\text { može da bude skupa. }\end{array}$ \\
\hline $\begin{array}{l}\text { Kompjuterski } \\
\text { zasnovano učenje }\end{array}$ & $\begin{array}{l}\text {-Omogućuje ostvarivanje } \\
\text { širokog osega obrazovnih } \\
\text { ciljeva; } \\
\text { =Omogućuje učeniku da } \\
\text { radi sopstvenom brzinom; } \\
\text {-Može da omogući } \\
\text { značajan stepen interakcije } \\
\text { između učenika i } \\
\text { instrukcionog programa i } \\
\text { može da se prilagodi } \\
\text { potrebama učenika; može u } \\
\text { velikoj meri da bude } \\
\text { stimulativno; } \\
\text {-Može da pruži iskustva u } \\
\text { učenju koja nam inače ne bi } \\
\text { bila dostupna. }\end{array}$ & $\begin{array}{l}\text {-Iste bazične slabosti kao } \\
\text { kod medijskih samostalnih } \\
\text { instrukcija; } \\
\text { - Zahteva i kompjutersku } \\
\text { pismenost i (u mnogim } \\
\text { slučajevima) prisustvo } \\
\text { visokog stepena večtine } \\
\text { programiranja kod } \\
\text { nastavnika. }\end{array}$ \\
\hline $\begin{array}{l}\text { Individualan } \\
\text { praktičan rad u } \\
\text { studiju ili rad na } \\
\text { projektu }\end{array}$ & $\begin{array}{l}\text { - Može da bude delotvoran } \\
\text { za razvijanje psiho- } \\
\text { motornih i njima srodnih } \\
\text { veština; } \\
\text {-Može da pomogne kod } \\
\text { demonstriranja relevantnosti } \\
\text { teorijskog sadržaja kursa; } \\
\text {-Učenici obično uživaju } \\
\text { zbog svog učesća u radu; } \\
\text { = Omogućuje učenicima da } \\
\text { rade sopstvenom brzinom. }\end{array}$ & $\begin{array}{l}\text { - Može da bude gubljenje } \\
\text { vremena ukoliko odabrane } \\
\text { aktivnosti nisu relevantne } \\
\text { za sadržaj kursa; } \\
\text {-Obično je skupo, u smislu } \\
\text { trošenja vremena, ljudskog } \\
\text { rada, opreme i materijala; } \\
\text {-Najčešce su rezultati slabi } \\
\text { u smislu ostvarivanja } \\
\text { kognitivnih ciljeva višeg } \\
\text { reda, osim ukoliko se ne } \\
\text { sprovede pažljivo } \\
\text { planiranje. }\end{array}$ \\
\hline
\end{tabular}


Primena multimedije, a šire posmatrano i IKT, imperativ je savremene nastave. To je uočljivo i u Strategiji razvoja informacionog društva u Srbiji (2010: 13), gde je Vlada Republike Srbije predvidela sledeće:

„Razvojem primene IKT u obrazovanju potrebno je postići:

$>$ uspostavljanje modernog obrazovnog sistema koji je prilagođen potrebama informacionog društva;

$>$ razvoj digitalnih obrazovnih sadržaja;

$>$ obučenost nastavnika za korišćenje IKT;

$>$ podizanje nivoa znanja i veština za korišćenje IKT kod najšire populacije;

$>$ osposobljenost za primenu IKT na radnom mestu na način kojim se podiže stepen efikasnosti, poboljšava kvalitet rada i obezbeđuju bolji poslovi;

$>$ uvođenje savremenog koncepta e-učenja i otvorenog učenja na daljinu;

$>$ da IKT bude integralni deo obrazovnih programa, obrazovni programi i nastavni procesi prilagođeni potrebama informacionog društva, a nastavni kadrovi osposobljeni za moderne oblike nastave;

$>$ razvoj koncepta obrazovanja i učenja tokom čitavog života;

$>$ uključivanje društvenih grupa sa posebnim obrazovnim potrebama, što obuhvata sticanje znanja i veština iz oblasti IKT odraslih, koji nisu imali mogućnosti da ih dobiju.

Potrebno je istovremeno podizati tehnološku osnovu u školama, uključujući informaciono-tehnološko opremanje i komunikaciono povezivanje škola, kao i preduzimati mere da se tehnološka osnova primeni zarad ispunjenja prethodno navedenih ciljeva."

\section{Zaključak}

Na kraju, može se reći da nijedan element obrazovne tehnologije nije savršen za prenošenje svakog sadržaja, za ostvarivanje svih ciljeva, a ni za sve uzraste učenika, njihove različite sposobnosti, kao i načine učenja. Za svaku primenu obrazovnih tehnologija potrebno je odrediti uloge i značenja pojedinih elemenata. Posebno važna pitanja prilikom upotrebe IKT za učenje i poučavanje jesu pitanja kriterijuma za izbor didaktičkog modela, kao i didaktičkih strategija koje su ugrađene u multimedij. dakle, suština multimedijalnosti je interaktivnost kao glavno obeležje medija. Kada se to prenese na polje nastavne situacije, onda možemo reći da primena multimedija u nastavi predstavlja emitovanje, tj. prikaz pedagoških-obrazovnih-nastavnih sadržaja putem međusobno povezanih interaktivnih medija, i omogućava različite metode i oblike učenja.

Savremena obrazovna tehnologija može biti instrument promena. Onda kada prosvetni radnici prihvate i otvore svoje poglede ka potencijalima obrazovne tehnologije, izaći će iz nepravilnog, zastarelog kruga predavanje-učenje-predavanje. 
Brz tempo promena na polju IKT-a, različitost i širina dostupnog znanja, primorava predavače da nastave sa učenjem i da budu u skladu sa vremenom, što ima pozitivan uticaj na učenike, i same predavače. Postoje opravdani razlozi za to jer nam je informaciona tehnologija sve više neophodna za učenje. Tehnologija je pre svega samo sredstvo, i može biti korišćena u bilo kojoj disciplini. Ona je takođe sredstvo koje se može efektivno koristiti za primenu četiri komponente procesa učenja i predavanja: individualizaciju, vertikalno povezivanje, horizontalno povezivanje, kao i stalnu inovaciju i stvaranje novih znanja.

\section{Literatura}

Collins, B. (1995). Societal and Organizational Influences on Integration. Integrating Information Technology in to Education, p.p. 249-262. London: Chapman\&Hall.

Danilović, M. (1996). Savremena obrazovna tehnologija. Beograd: Institut za pedagoška istraživanja.

Dichanz, H. (1999). Schule und Multimedia. V: Sandler, U.(ur.). Multimedia. Neuwied.

Dillon, A. \& Gabbard, R. (1998). Hypermedia as an educational technologie. Review of educational research. pp. 68.

Kapur, A. (2011). Transforming Schools - Empowering Children. New Delhi, Thousand Oaks, London: SAGE Publication.

Papert, S. (1980). Mindstorms: Children, computers, and Powerful Ideas. New York: Basic Books.

Strategija razvoja informacionog društva u Republici Srbiji do 2020. godine. (2010). [online] Retrived from: http://mtt.gov.rs/download/3/Strategija_razvoja_informacionog_drustva_2020.pdf (Accessed 12.7.2017.)

Wenglinsky, H. (1998). Does it computer? ETS policy information.

Williams, B. K. et al. (1995). Using Information Technology. Chicago, Bogota, Boston, Buenos Aires, Caracas, London, Madrid,Mexico City, Sidney, Toronto: Irwin.

\section{DIDACTICAL APPROACH TO THE USE OF ICT IN THE TEACHING PROCESS}

\section{Zoran Stanković,}

University of Niš, Faculty of Philosophy in Niš, Department of Pedagogy

\section{Dragana Stanojević}

University of Niš, Pedagogical Faculty in Vranje,

Abstract: Modern educational technology occupies a more important place in the teaching process. Among other things, its fundamental role is reflected in the selection 
of methods and synchronized combination of different device for classes with the use of information and communication technology (ICT) and multimedia packages for learning, which are appropriate to the age and needs of students. With adequate implementation, students are enabled the ability to think rationally, analyze, conclude and achieve significantly better results that lead to more efficient active and permanent acquisition of knowledge.

The main objective of this work is to draw attention to the general pedagogical expert and scientific public, and to point to a wider spectrum of roles and opportunities provided by the use of ICT in the teaching process. In this sense, this paper, in addition to theoretical considerations observed through the prism of didactic, transmitted and analyzed some positive foreign experience from teaching practice.

Keywords: educational technology, ICT, multimedia, educational software, teaching process.

\section{Citiranje članka:}

Stanković, Z. i Stanojević, D. (2017). Didaktički pristupi upotrebe IKT u nastavnom procesu. Godišnjak za pedagogiju, 2(1), 41-49. 
